\title{
Genetic Variability, Correlation and Path Coefficient Analysis for Yield and Its Attributing Traits in Cowpea [Vigna unguiculata (L.) Walp] Accessions
}

\author{
A. R. Chaudhary ${ }^{1}$, S. D. Solanki ${ }^{1}$, P. M. Rahevar ${ }^{2 *}$ and D. A. Patel ${ }^{1}$ \\ ${ }^{1}$ Department of Genetics and Plant Breeding, C.P. College of Agriculture, S. D. Agricultural \\ University, Sardarkrushinagar - 385 506, Gujarat, India \\ ${ }^{2}$ S. D. Agriculture University, Sardarkrushinagar - 385 506, Gujarat, India \\ *Corresponding author
}

\begin{tabular}{|l}
\hline Ke y w o r d s \\
Cowpea, GCV, \\
PCV, Correlation \\
and Path analysis
\end{tabular}

\section{A B S T R A C T}

Cowpea [Vigna unguiculata (L.) walp.]; also known as a black-eyed pea or Southern pea is self-pollinated crop belongs to the family Fabaceae. In this experimentation, thirty accessions were evaluated for eleven agro-morphological traits at agronomy instructional farm, C. P. College of agriculture, S. D. A. U., Sardarkrushinagar under high temperature using randomized block design (RBD) and three replications. Analysis of variance revealed significant variation for all the eleven agro-morphological traits under study. The genotypic coefficient of variation, heritability and genetic advance were observed highest for seed yield per plant followed by number of pods per plant and leaf area per plant. Significant positive correlation was found between seed yield per plant and number of pods per plant; number of seeds per pod; number of branches per plant; pod length and plant height. Whereas, negative significant correlation was observed between seed yield per plant with days to flowering and days to maturity. In the present studies pod length recorded the highest positive direct effect on seed yield per plant followed by number of branches per plant and number of pods per plant. While, days to flowering had highest negative direct effect on seed yield per plant. Both correlation and path analyses indicated that number of pods per plant, number of seeds per pod, number of branches per plant and pod length were the major direct contributors to seed yield.

\section{Introduction}

Cowpea [Vigna unguiculata (L.) walp.] is self-pollinated crop, belongs to family Fabaceae and sub family Papillonaceae with chromosome number $2 n=2 x=22$. It is an important grain legume crop in developing countries of the tropics and subtropics, especially in sub-Saharan Africa, Asia, Central and South America (Singh et al.,
1997). It is a pantropical herbaceous nitrogen fixing plant known by a variety of names, but cowpea is the most popular worldwide name. In the United States, it is called blackeyed beans, black-eyed peas or southern peas, whereas in Indian and Brazil, it is referred to as lobia and caupi, respectively. In French speaking countries of Africa, Niebe is the common name, but there are local names depending on the ethnical groups, such as 
'niao' in Senegal, 'wake' in Nigeria and 'lubahilu' in the Sudan (Diouf, 2011). According to Vedcourt (1970), there are five sub species of Vigna unguiculata (L.) Walp. among which two are wild viz., dekinditiana and mensensis whereas, remaining three species are cultivated and wide spread in India (Steel, 1976) which are unguiculata, sinensis (common cowpea), sesquipedalis (asparagus bean or yard long bean). Vavilov (1949), recognized India and Africa as the centres of origin, while China is considered as secondary centre of origin of cowpea. Cowpea is considerable as one of the most widely adapted and versatile crops which can tolerate to high temperatures and drought compared to other crop species. In India, cowpea is mainly cultivated for fodder, green manure and soil improving cover crop (ICAR-CCARI). Green pods of cowpea are used as vegetable in Northern Indian States whereas in West Bengal, Tamil Nadu, Andhra Pradesh, Kerala and Maharashtra cowpea is cultivated as a pulse crop. Cowpea is grown over an area of 14 million ha with a production of 4.5 million tones and the productivity of $387 \mathrm{~kg}$ per ha (Anonymous, 2019). India ranks second in vegetable production from 58.5 million tonnes in 199192 to 175 million tonnes in 2016-17. Both grain and leaves are edible products of cowpea that are rich and cheap sources of high-quality protein. The crop can fix about $240 \mathrm{~kg}$ per ha of atmospheric nitrogen and make available about $60-70 \mathrm{~kg}$ per ha for the succeeding crops grown in rotation with it (Aikins and Afuakwa, 2008; Kamau and Weru, 2001).

\section{Materials and Methods}

The present investigation was carried out at agronomy instructional farm, C. P. College of agriculture, S. D. Agricultural University, Sardarkrushinagar during summer season of 2018 in randomized block design (RBD) with three replications. The experimental material was comprised of thirty genotypes of cowpea, collected from pulses research station, S. D. Agricultural University, Sardarkrushinagar and vegetable research station, Anand Agricultural University, Anand, Gujarat. The genotypes were evaluated for following traits viz., days to flowering, days to maturity, plant height $(\mathrm{cm})$, number of branches per plant, number of pods per plant, number of seeds per pod, length of pod $(\mathrm{cm})$, test weight $(\mathrm{g})$, seed yield per plant, protein content (\%) and leaf area per plant $\left(\mathrm{cm}^{2}\right)$. The plot size was $432 \mathrm{~m}^{2}$ with inter row spacing of $45 \mathrm{~cm}$ and intra row spacing of $15 \mathrm{~cm}$. The data were recorded from five randomly selected plants from each entry in each replication and mean values were calculated for statistical analysis. The analysis of variance was done as suggested by Panse and Sukhatme (1978). Genotypic coefficient of variation (GCV) and Phenotypic Coefficient of Variation (PCV) were estimated as per Burton (1952); Heritability $\left(\mathrm{h}^{2}\right)$ and Genetic Advance (GA) were estimated according to Johnson et al., (1955a). Analysis of variance for all possible pairs of eleven characters was carried out using the procedure of Panse and Sukhatme (1978) and path analysis was done following Dewey and Lu (1959). All the statistical analysis was performed at department of agricultural statistics using INDOSTAT v8.1.

\section{Results and Discussion}

All the eleven characters under investigation showed highly significant variation amid the genotypes signifying their prominence in the study of genetic variability (Table 1). The significance of genotype difference indicates the presence of variability for each of the characters among the tested entries (Haile, et al., 2015). Availability of variability in the material is of enormous importance for the success of any breeding programme. Mean performance, range and coefficient of 
variance $(\mathrm{CV})$ of all genotypes for different traits are given in Table 2. The lower the value of the coefficient of variation (Range: 4.20 to 13.58 ), more precise the estimate (INSEE, 2019).

\section{Genetic variability}

Estimates for the GCV, PCV, heritability in broad sense $\left(\mathrm{h}^{2}\right)$ and GA as $\%$ of mean are presented in the Table 3. High phenotypic coefficient of variation than genotypic coefficients of variation for all the traits in the study might be due to environmental error. The GCV and PCV were highest for seed yield per plant (55.51 and 57.14 respectively) followed by number of pods per plant (45.49 and 47.42 respectively), leaf area per plant (38.15 and 39.34 respectively) and number of seeds per pod (20.74 and 23.56respectively). Vicinities amongst GCV and PCV for all the traits excluding days to flowering, plant height, number of branches per plant and number of seeds per pod; Indicated that these characters were controlled by the genetic makeup of the genotypes. The wide range of GCV and PCV defines greater variability among the genotypes and thus, better improvement is possible by selection. Higher estimate of genotypic and phenotypic coefficient of variation were observed for seed yield per plant, number of pods per plant, leaf area per plant and number of seeds per pod. Moderate estimates of genotypic and phenotypic coefficient of variation were observed for test weight, pod length and number of branches per plant. While lowest estimates of genotypic and phenotypic coefficient variation were observed for plant height, days to maturity, days to flowering and protein content. Similar results were obtained by Sawant (1994) for days to flowering, days to maturity, number of branches per plant, test weight and seed yield per plant; Rangaiah and Mahadevu (1999) for test weight and seed yield per plant;
Narayanankutty et al. (2003) for days to flowering, days to maturity and seed yield per plant; Nigude et al. (2004) for days to maturity, number of branches per plant, test weight and leaf area; Resmi et al. (2004) for number of branches per plant and seed yield per plant; Khan et al. (2013) for days to flowering, number of branches per plant, test weight and seed yield per plant; Vir and Singh (2014) for seed yield per plant, test weight, number of branches per plant and days to flowering. Thorat and Gadewar (2013) for number of pods per plant, pod length and protein content.

GCV and the $\mathrm{h}^{2}$ estimates were drove out to determine the level of heritable variation. The GCV determine the extreme success of selection and heritability specifies how closely the goal can be accomplished. The high estimates of heritability in the quantitative characters are useful since these values helps in the selection on the basis of phenotypic performance (Sarkar et al. 2009). Johnson et al. (1955) suggested that heritability estimates along with genetic gain is usually more helpful than the heritability alone for selecting superior individuals. The heritability (b.s.) estimate ranged from $12.75 \%$ (days to flowering) to $94.40 \%$ (seed yield per plant). Seed yield per plant (94.40\%), leaf area per plant $(94.08 \%)$, number of pods per plant $(92.00 \%)$, pod length $(87.26 \%)$, test weight $(79.40 \%)$, number of seeds per pod (77.53\%) showed high heritability indicates that these characters are least influenced by the environmental effects, the selection for improvement of such characters may not be useful because broad sense heritability is based on total genetic variance which includes both fixable (additive) and nonfixable variance (dominance and epistatic). The lowest heritability for days to flowering $(12.75 \%)$ indicates that such characters are highly influenced by the environmental effects and genetic improvement through 
selection will be difficult due to masking effect of the environment on the genotypic effect. The moderate heritability was found in number of branches per plant (59.28\%), plant height $(41.03 \%)$, days to maturity $(37.70 \%)$ and protein content $(34.01 \%)$. These results were in conformity with the reports of Biradar et al. (1993), Nigude et al. (2004), Sarath and Reshma (2017), Srinivas (2017) and Thorat and Gadewar (2013).

High heritability coupled with high genetic advance was observed for number of pods per plant, number of seeds per pod, pod length, test weight, seed yield per plant and leaf area per plant specified that these characters were governed by the additive action of polygene and might be considered for selection criteria. Simple selection for such traits should be practiced for improving them. Biradar et al. (1993) reported same results for most the yield component, Narayanankutty et al. (2003) reported same results for seed yield per plant, pods per plant and pod weight, Nigude et al. (2004) reported same results for plant height, seed yield, test weight, number of pods per plant and pod length, Reshmi et al. (2004) reported same results for seed yield per plant, khanpara (2015) reported same result for seed yield per plant and Sarath and Reshma (2017) reported same results for plant height, seed yield per plant and number of branches per plant.

\section{Correlation}

Genotypic and phenotypic correlations presented in Table 4 and 5 respectively, indicated that seed yield per plant to have high, significant and positive association with number of pods per plant $\left(\mathrm{r}_{\mathrm{g}}=0.8464^{* *}\right.$ and $\left.\mathrm{r}_{\mathrm{p}}=0.8131^{* *}\right)$ followed by number of seeds per pod $\left(\mathrm{r}_{\mathrm{g}}=0.7174 * *\right.$ and $\left.\mathrm{r}_{\mathrm{p}}=0.6534 * *\right)$ and pod length $\left(r_{\mathrm{g}}=0.5494 * *\right.$ and $\left.\mathrm{r}_{\mathrm{p}}=0.5001 * *\right)$ at both genotypic and phenotypic level substantiating the findings of Kumar et al.
(2001), Nigude et al. (2004), Cholin et al. (2012) and Thorat and Gadewar (2013). Days to flowering $\left(\mathrm{r}_{\mathrm{g}}=-0.5860^{* *}\right)$ and maturity $\left(r_{\mathrm{g}}=-0.4628^{* *}\right) \quad$ exhibiting significant negative correlation with seed yield. Alike results have previously described by Vir and Singh (2014). Therefore, seed yield could be increased through selection in the component characters like number of pods per plant, number of seeds per pod and pod length. Kumar et al. (2001) for number of branches per plant and number of pods per plant; Nigude et al. (2004) for number of pods per plant and number of branches per plant; Cholin et al. (2012) number of branches per plant and number of pods per plant and Patel et al. (2016) for number of branches per plant; Thorat and Gadewar (2013) for days to flowering, days to maturity, number of seeds per pod, pod length, test weight, protein content and leaf area per plant reported similar results as observed in the present study. Days to flowering associated positively with days to maturity at both the levels which is supported by Vir and Singh (2014). The number of branches per plant showed significant positive association at both genotypic and phenotypic levels with seed yield per plant as recorded by Kumar et al. (2013).

\section{Path coefficient analysis}

To describe the phenotypic correlation values further path coefficient analysis was done to identify characters having significant direct and indirect effects on grain yield (Table 6). Highest positive direct effect on yield was registered by the pod length (0.7762) followed by number of branches per plant (0.6779) and number of pods per plant (0.4633) which was also reported earlier by Venkatesan (2003), Deepa and Balan (2006), Lal (2007), Vishwanath and Rai (2009), Udensi and Ikpeme (2012), Cholin (2012) Patel (2016). Interestingly, these characters 
also exhibited significant positive correlation with yield and therefore, should be considered as important selection criteria for yield improvement of cowpea. While, plant height $(-0.0083)$, leaf area per plant $(-0.2524)$, test weight $(-0.7864)$, protein content $(-1.1413)$ and days to flowering $(-1.4190)$ had negative direct effect on seed yield per plant. This result was in accordant with Jogdhande (2017). Residual effect of the path analysis was medium (0.5530) suggesting the characters considered in the study was ample and defensible.

Table.1 Analysis of variance for different characters in cowpea

\begin{tabular}{|l|l|c|c|c|}
\hline Sr.No & Character & \multicolumn{3}{|c|}{ Mean sum of square } \\
\cline { 3 - 5 } & & Replication & Treatment & Error \\
\hline & Degree of freedom & 2 & 29 & 58 \\
\hline $\mathbf{1}$ & Days to Flowering & 0.30 & $14.69^{* * *}$ & 10.21 \\
\hline $\mathbf{2}$ & Days to maturity & 1.23 & $29.87^{* *}$ & 10.58 \\
\hline $\mathbf{3}$ & Plant height & 6.18 & $133.80^{* *}$ & 43.33 \\
\hline $\mathbf{4}$ & $\begin{array}{l}\text { Number of branches per } \\
\text { plant }\end{array}$ & 0.75 & $4.83^{* *}$ & 0.90 \\
\hline $\mathbf{5}$ & Number of pods per plant & 11.51 & $341.56^{* *}$ & 9.62 \\
\hline $\mathbf{6}$ & Number of seeds per pod & 1.24 & $12.29^{* *}$ & 1.08 \\
\hline $\mathbf{7}$ & Pod Length & 0.28 & $13.08^{* * *}$ & 0.60 \\
\hline $\mathbf{8}$ & Test weight & 0.20 & $14.09^{* *}$ & 1.12 \\
\hline $\mathbf{9}$ & Seed yield per plant & 9.36 & $496.08^{* *}$ & 9.69 \\
\hline $\mathbf{1 0}$ & Protein content & 0.97 & $2.20^{* *}$ & 0.87 \\
\hline $\mathbf{1 1}$ & Leaf area per plant & 0.53 & $1204368.85^{* *}$ & 24732.16 \\
\hline
\end{tabular}

$*, * *$ significant at $5 \%$ and $1 \%$ level of significance, respectively.

Table.2 Mean, range and coefficient of variance for quantitative Characters

\begin{tabular}{|l|l|c|c|c|c|}
\hline Sr.No & \multicolumn{1}{|c|}{ Character } & Mean & \multicolumn{2}{|c|}{ Range } & \multirow{2}{*}{ C.V } \\
\cline { 1 - 3 } & & & Min. & Max. & \\
\hline $\mathbf{1}$ & Days to Flowering & 53.73 & 49.30 & 57.64 & 5.94 \\
\hline $\mathbf{2}$ & Days to maturity & 68.37 & 63.64 & 74.98 & 4.75 \\
\hline $\mathbf{3}$ & Plant height & 56.2 & 43.13 & 74.47 & 11.71 \\
\hline $\mathbf{4}$ & $\begin{array}{l}\text { Number of branches per } \\
\text { plant }\end{array}$ & 8.59 & 5.00 & 10.80 & 11.05 \\
\hline $\mathbf{5}$ & Number of pods per plant & 23.12 & 3.20 & 42.00 & 13.41 \\
\hline $\mathbf{6}$ & Number of seeds per pod & 9.32 & 2.07 & 14.43 & 11.17 \\
\hline $\mathbf{7}$ & Pod Length & 12.41 & 5.40 & 17.35 & 6.28 \\
\hline $\mathbf{8}$ & Test weight & 10.48 & 7.42 & 15.77 & 10.10 \\
\hline $\mathbf{9}$ & Seed yield per plant & 22.94 & 0.94 & 51.32 & 13.58 \\
\hline $\mathbf{1 0}$ & Protein content & 22.14 & 19.87 & 23.44 & 4.20 \\
\hline $\mathbf{1 1}$ & Leaf area per plant & 1643.32 & 687.44 & 3192.83 & 9.57 \\
\hline
\end{tabular}


Table.3 Genetic parameters of variation for seed yield and its contributing characters in cowpea

\begin{tabular}{|c|c|c|c|c|c|c|c|c|}
\hline \multirow{2}{*}{$\begin{array}{l}\text { Sr. } \\
\text { No. }\end{array}$} & \multirow[t]{2}{*}{ Characters } & \multicolumn{7}{|c|}{ Genetic parameters } \\
\hline & & $\sigma_{g}^{2}$ & $\sigma_{p}^{2}$ & $\operatorname{GCV}(\%)$ & PCV $(\%)$ & $\mathrm{h}^{2}(\%)$ & GA & GAM $(\%)$ \\
\hline 1 & Days to flowering & 1.49 & 11.71 & 02.27 & 6.36 & 12.75 & 0.89 & 1.67 \\
\hline 2 & Days to maturity & 6.42 & 17.01 & 03.70 & 6.03 & 37.70 & 3.20 & 4.69 \\
\hline 3 & Plant height & 30.15 & 73.49 & 09.77 & 15.25 & 41.03 & 7.24 & 12.89 \\
\hline 4 & Number of branches per plant & 1.31 & 2.21 & 13.33 & 17.31 & 59.28 & 1.81 & 21.14 \\
\hline 5 & Number of pods per plant & 110.64 & 120.26 & 45.49 & 47.42 & 92.00 & 20.78 & 89.88 \\
\hline 6 & Number of seeds per pod & 3.73 & 4.81 & 20.74 & 23.56 & 77.53 & 3.50 & 37.63 \\
\hline 7 & Pod length & 4.15 & 4.76 & 16.43 & 17.59 & 87.26 & 3.92 & 31.62 \\
\hline 8 & Test weight & 4.32 & 5.44 & 19.83 & 22.26 & 79.40 & 3.81 & 36.41 \\
\hline 9 & Seed yield per plant & 162.12 & 171.82 & 55.51 & 57.14 & 94.40 & 25.47 & 111.07 \\
\hline 10 & Protein content & 0.44 & 1.31 & 03.01 & 5.17 & 34.01 & 0.80 & 3.62 \\
\hline 11 & Leaf area per plant & 393212 & 417944 & 38.15 & 39.34 & 94.08 & 12.52 & 76.24 \\
\hline
\end{tabular}

$\sigma_{\mathrm{g}}^{2}=$ Genotypic variance, $\sigma_{\mathrm{p}}^{2}=$ Phenotypic variance, $\mathrm{GCV}=$ Genotypic coefficient of variation, $\mathrm{PCV}=$ Phenotypic coefficient of variation, $\mathrm{h}^{2}(\%)=\mathrm{Heritability}$, $\mathrm{GA}=$ Genetic advance, GAM $(\%)=$ Genetic advance as per cent of mean 
Table.4 Genotypic correlation coefficient for different characters in cowpea

\begin{tabular}{|c|c|c|c|c|c|c|c|c|c|c|c|c|}
\hline \multirow[t]{2}{*}{$\begin{array}{l}\text { Sr. } \\
\text { no. }\end{array}$} & \multirow[t]{2}{*}{ Characters } & \multirow{2}{*}{$\begin{array}{l}\text { Days to } \\
\text { flowerin } \\
\mathrm{g}\end{array}$} & \multirow{2}{*}{$\begin{array}{l}\text { Days to } \\
\text { maturit } \\
\mathbf{y}\end{array}$} & \multirow[t]{2}{*}{$\begin{array}{l}\text { Plant } \\
\text { height }\end{array}$} & \multirow{2}{*}{$\begin{array}{l}\text { Number of } \\
\text { branches } \\
\text { /plant }\end{array}$} & \multirow{2}{*}{$\begin{array}{l}\text { Number } \\
\text { of pods/ } \\
\text { plant }\end{array}$} & \multirow{2}{*}{$\begin{array}{l}\text { Number } \\
\text { of seeds/ } \\
\text { pod }\end{array}$} & \multirow[t]{2}{*}{$\begin{array}{l}\text { Pod } \\
\text { length }\end{array}$} & \multirow[t]{2}{*}{$\begin{array}{l}\text { Test } \\
\text { weight }\end{array}$} & \multirow[t]{2}{*}{$\begin{array}{l}\text { Protein } \\
\text { content }\end{array}$} & \multirow{2}{*}{$\begin{array}{c}\text { Leaf } \\
\text { area/plan } \\
\mathbf{t}\end{array}$} & \multirow{2}{*}{$\begin{array}{c}\text { Seed } \\
\text { yield/plan }\end{array}$} \\
\hline & & & & & & & & & & & & \\
\hline 1 & Days to flowering & 1.0000 & $\begin{array}{l}0.7211^{*} \\
*\end{array}$ & 0.1499 & -0.0983 & $-0.9531 * *$ & $-0.4169 * *$ & $-\overline{0.3596 * *}$ & $0.2262 *$ & $-\overline{0.6106 * *}$ & -0.1133 & $-0.5860 * *$ \\
\hline 2 & Days to maturity & & 1.0000 & 0.1365 & $-0.4240 * *$ & $-0.4465 * *$ & $-0.2234 *$ & $-{ }^{-} .2875^{* *}$ & $-\overline{0.4160 * *}$ & $-0.2105^{*}$ & 0.1274 & $-0.4628 * *$ \\
\hline 3 & Plant height & & & 1.0000 & $0.2290^{*}$ & 0.0363 & $0.7575 * *$ & $0.5181 * *$ & $-\overline{0.2880 * *}$ & 0.1956 & $0.9906 * *$ & $0.2631 *$ \\
\hline 4 & $\begin{array}{c}\text { Number of } \\
\text { branches/plant }\end{array}$ & & & & 1.0000 & $0.2561 *$ & $0.3272 * *$ & 0.0806 & $0.2872 * *$ & 0.0417 & 0.0028 & $0.3881 * *$ \\
\hline 5 & Number of pods/plant & & & & & 1.0000 & $0.5183 * *$ & $0.2435^{*}$ & $-0.2476^{*}$ & $0.4169 * *$ & $0.2131 *$ & $0.8464 * *$ \\
\hline 6 & Number of seeds/pod & & & & & & 1.0000 & $0.7069 * *$ & -0.1721 & $0.4432 * *$ & $0.5120 * *$ & $0.7174 * *$ \\
\hline 7 & Pod length & & & & & & & 1.0000 & $0.3448 * *$ & $0.2751 * *$ & $0.4479 * *$ & $0.5494 * *$ \\
\hline 8 & Test weight & & & & & & & & 1.0000 & $-\overline{0.6271 * *}$ & $-0.3183 * *$ & 0.0819 \\
\hline 9 & Protein content & & & & & & & & & 1.0000 & 0.2001 & $0.2184^{*}$ \\
\hline 10 & Leaf area per plant & & & & & & & & & & 1.0000 & $0.3147 * *$ \\
\hline 11 & Seed yield per plant & & & & & & & & & & & 1.0000 \\
\hline
\end{tabular}

*, ** significant at $0.05 \%$ and $0.01 \%$ level of significance, respectively. 
Table.5 Phenotypic correlation coefficient for different characters in cowpea

\begin{tabular}{|c|c|c|c|c|c|c|c|c|c|c|c|c|}
\hline $\begin{array}{l}\text { Sr. } \\
\text { no. }\end{array}$ & Characters & $\begin{array}{c}\text { Days to } \\
\text { flowerin } \\
\mathrm{g}\end{array}$ & $\begin{array}{c}\text { Days to } \\
\text { maturit } \\
y\end{array}$ & $\begin{array}{l}\text { Plant } \\
\text { height }\end{array}$ & $\begin{array}{c}\text { Number of } \\
\text { branches } \\
\text { /plant }\end{array}$ & $\begin{array}{l}\text { Number } \\
\text { of pods } \\
\text { /plant }\end{array}$ & $\begin{array}{c}\text { Number } \\
\text { of seeds } \\
\text { /pod }\end{array}$ & $\begin{array}{l}\text { Pod } \\
\text { length }\end{array}$ & $\begin{array}{c}\text { Test } \\
\text { weight }\end{array}$ & $\begin{array}{l}\text { Protein } \\
\text { content }\end{array}$ & $\begin{array}{c}\text { Leaf } \\
\text { area/plant }\end{array}$ & $\begin{array}{c}\text { Seed } \\
\text { yield/plan } \\
\mathbf{t}\end{array}$ \\
\hline 1 & Days to flowering & 1.0000 & $0.2269 *$ & 0.0500 & -0.1641 & $-0.3448 * *$ & -0.0534 & -0.0872 & 0.0784 & -0.2033 & -0.0384 & -0.2078 \\
\hline 2 & Days to maturity & & 1.0000 & 0.1346 & $-0.3066^{* *}$ & $-0.2510 *$ & -0.1477 & -0.1617 & $-0.2631 *$ & -0.0530 & 0.0796 & $-0.2920 * *$ \\
\hline 3 & Plant height & & & 1.0000 & 0.1751 & 0.0175 & $0.3730 * *$ & $\begin{array}{c}0.3160 * \\
*\end{array}$ & -0.2061 & 0.0284 & $0.6351 * *$ & 0.1259 \\
\hline 4 & $\begin{array}{c}\text { Number of branches } \\
\text { /plant }\end{array}$ & & & & 1.0000 & $0.2229 *$ & 0.2000 & 0.0777 & 0.1975 & 0.0224 & 0.0256 & $0.2758 * *$ \\
\hline 5 & Number of pods/plant & & & & & 1.0000 & $0.4427 * *$ & $0.2257 *$ & $-0.2182^{*}$ & 0.2051 & $0.2076^{*}$ & $0.8131 * *$ \\
\hline 6 & Number of seeds/pod & & & & & & 1.0000 & $\begin{array}{c}0.6052 * \\
*\end{array}$ & -0.0830 & $0.3158 * *$ & $0.4516 * *$ & $0.6534 * *$ \\
\hline 7 & Pod length & & & & & & & 1.0000 & $\begin{array}{c}0.2860 * \\
*\end{array}$ & 0.1408 & $0.4086^{* *}$ & $0.5001 * *$ \\
\hline 8 & Test weight & & & & & & & & 1.0000 & $-0.3977 * *$ & $-0.2761 * *$ & 0.1260 \\
\hline 9 & Protein content & & & & & & & & & 1.0000 & 0.1194 & 0.1247 \\
\hline 10 & Leaf area per plant & & & & & & & & & & 1.0000 & $0.2980 * *$ \\
\hline 11 & Seed yield/plant & & & & & & & & & & & 1.0000 \\
\hline
\end{tabular}


Table.6 Direct and indirect effects of yield components on seed yield in cowpea

\begin{tabular}{|c|c|c|c|c|c|c|c|c|c|c|c|c|}
\hline $\begin{array}{l}\text { Sr. } \\
\text { no. }\end{array}$ & Characters & $\begin{array}{c}\text { Days to } \\
\text { flowerin } \\
\mathrm{g}\end{array}$ & $\begin{array}{c}\text { Days to } \\
\text { maturit } \\
y\end{array}$ & $\begin{array}{c}\text { Plant } \\
\text { height }\end{array}$ & $\begin{array}{c}\text { Number of } \\
\text { branch/pla } \\
\text { nt }\end{array}$ & $\begin{array}{c}\begin{array}{c}\text { Number } \\
\text { of } \\
\text { pod/plant }\end{array} \\
\end{array}$ & $\begin{array}{c}\text { Number } \\
\text { of } \\
\text { seed/pod }\end{array}$ & $\begin{array}{c}\text { Pod } \\
\text { length }\end{array}$ & $\begin{array}{c}\text { Test } \\
\text { weight }\end{array}$ & $\begin{array}{l}\text { Protein } \\
\text { content }\end{array}$ & $\begin{array}{c}\text { Leaf } \\
\text { area/plan } \\
\mathbf{t}\end{array}$ & $\begin{array}{c}\text { Seed } \\
\text { yield/plan } \\
\text { t }\end{array}$ \\
\hline 1 & Days to flowering & -1.4190 & 0.2677 & 0.0013 & -0.0666 & 0.4415 & -0.0769 & $\begin{array}{c}- \\
0.2791\end{array}$ & $\begin{array}{c}- \\
0.1779\end{array}$ & 0.6969 & 0.0286 & -0.5860 \\
\hline 2 & Days to maturity & -1.0233 & 0.3713 & 0.0011 & -0.2874 & 0.2068 & -0.0412 & 0.2231 & 0.3272 & 0.2403 & -0.0321 & -0.4628 \\
\hline 3 & Plant height & -0.2127 & 0.0507 & $\begin{array}{c}- \\
0.0083\end{array}$ & 0.1553 & -0.0168 & 0.1397 & 0.4022 & 0.2265 & -0.2233 & -0.2500 & 0.2631 \\
\hline 4 & $\begin{array}{c}\text { Number of } \\
\text { branch/plant }\end{array}$ & 0.1395 & -0.1574 & $\begin{array}{c}- \\
0.0019\end{array}$ & 0.6779 & -0.1187 & 0.0603 & 0.0626 & 0.2259 & -0.0476 & -0.0007 & 0.3881 \\
\hline 5 & Number of pod/plant & 1.3525 & -0.1658 & $\begin{array}{c}- \\
0.0003\end{array}$ & 0.1736 & 0.4633 & 0.0956 & 0.1890 & 0.1947 & -0.4758 & -0.0538 & 0.8464 \\
\hline 6 & Number of seed/pod & 0.5916 & -0.0830 & $\begin{array}{c}- \\
0.0063\end{array}$ & 0.2218 & 0.2401 & 0.1844 & 0.5487 & 0.1354 & -0.5058 & -0.1292 & 0.7174 \\
\hline 7 & Pod length & 0.5102 & -0.1067 & $\begin{array}{c}- \\
0.0043\end{array}$ & 0.0547 & 0.1128 & 0.1304 & 0.7762 & $\begin{array}{c}- \\
0.2711\end{array}$ & -0.3140 & -0.1130 & 0.5494 \\
\hline 8 & Test weight & -0.3210 & -0.1545 & 0.0024 & 0.1947 & 0.1147 & -0.0311 & 0.2676 & $\begin{array}{c}- \\
0.7864\end{array}$ & 0.7158 & 0.0803 & 0.0819 \\
\hline 9 & Protein content & 0.8664 & -0.0782 & $\begin{array}{c}- \\
0.0016\end{array}$ & 0.0283 & -0.1931 & 0.0817 & 0.2136 & $\begin{array}{c}- \\
0.4932\end{array}$ & -1.1413 & -0.0505 & 0.2184 \\
\hline 10 & Leaf area per plant & 0.1608 & 0.0473 & $\begin{array}{c}- \\
0.0083\end{array}$ & 0.0019 & -0.0987 & 0.0944 & 0.3477 & 0.2503 & -0.2284 & -0.2524 & 0.3147 \\
\hline
\end{tabular}


Fig.1 Graphical comparison of GCV, PCV, heritability (b.s) and genetic advance as per cent of mean for eleven characters in cowpea

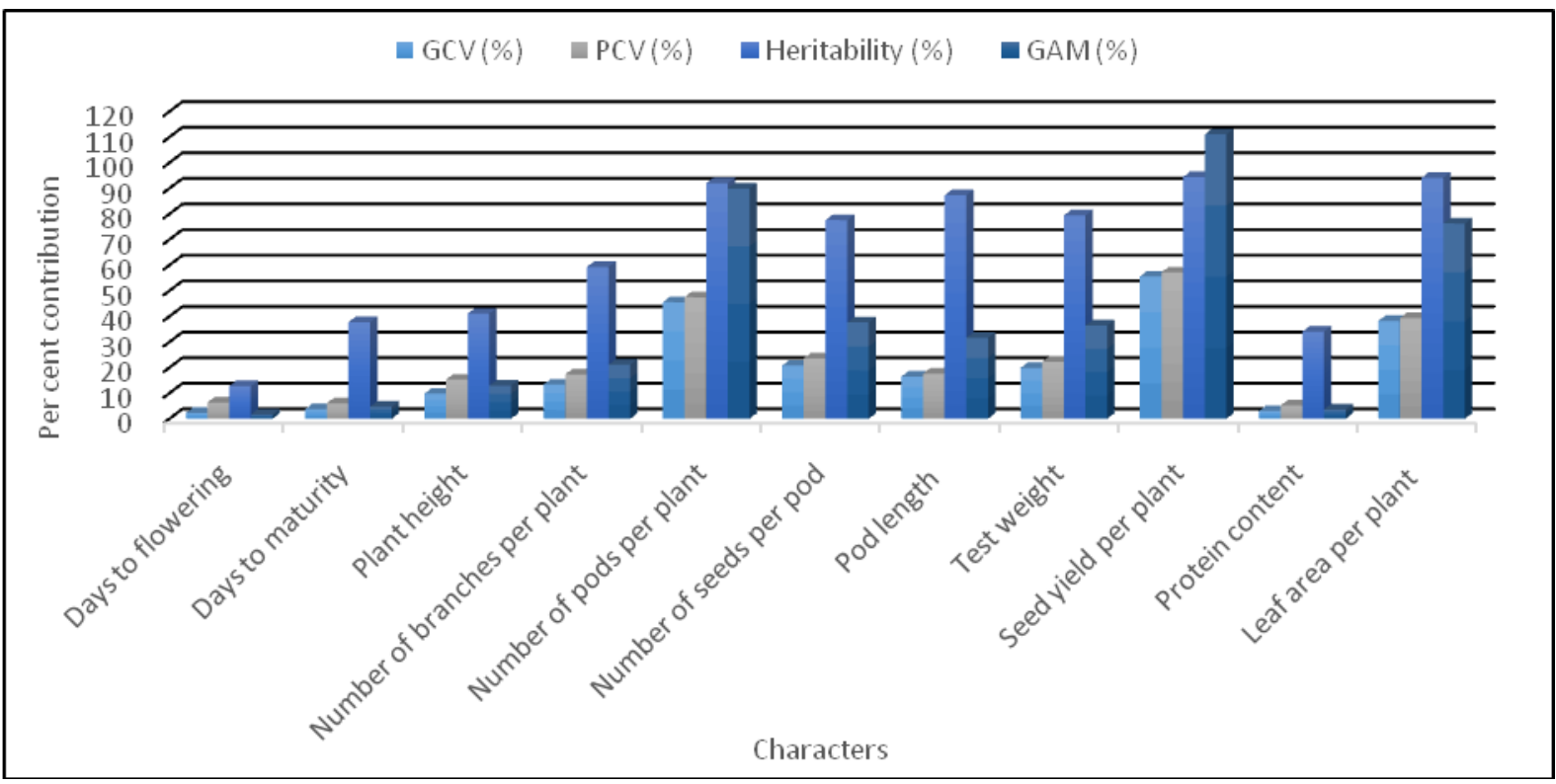

Fig.2 Genotypic path diagram for seed yield per plant

Fig III: Variability in seed colour

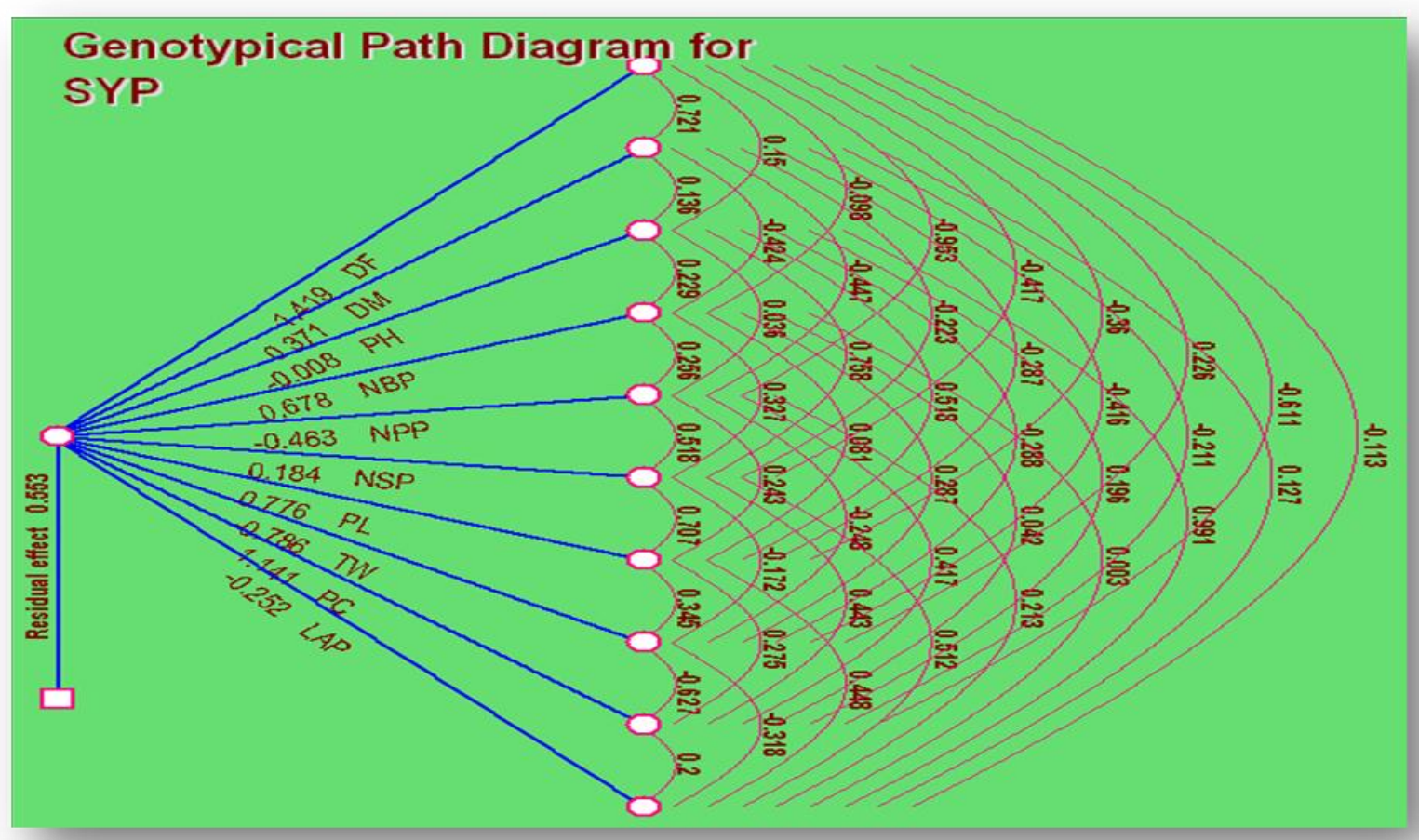

Where,

$\mathrm{DF}=$ Days to flowering, $\mathrm{DM}=$ Days to maturity, $\mathrm{PH}=\mathrm{Plant}$ height $(\mathrm{cm}), \mathrm{NBP}=\mathrm{Number}$ of branches per plant, $\mathrm{NPP}=$ Number of pods per plant, NSP=Number of seeds per pod, $\mathrm{PL}=$ Pod length $(\mathrm{cm}), \mathrm{TW}=$ Test weight $(\mathrm{g})$, $\mathrm{SYP}=$ Seed yield per plant $(\mathrm{g}), \mathrm{LAP}=$ Leaf area per plant $\left(\mathrm{cm}^{2}\right), \mathrm{PC}=$ Protein content $\%$. 
Fig.3 Variability in seed colour

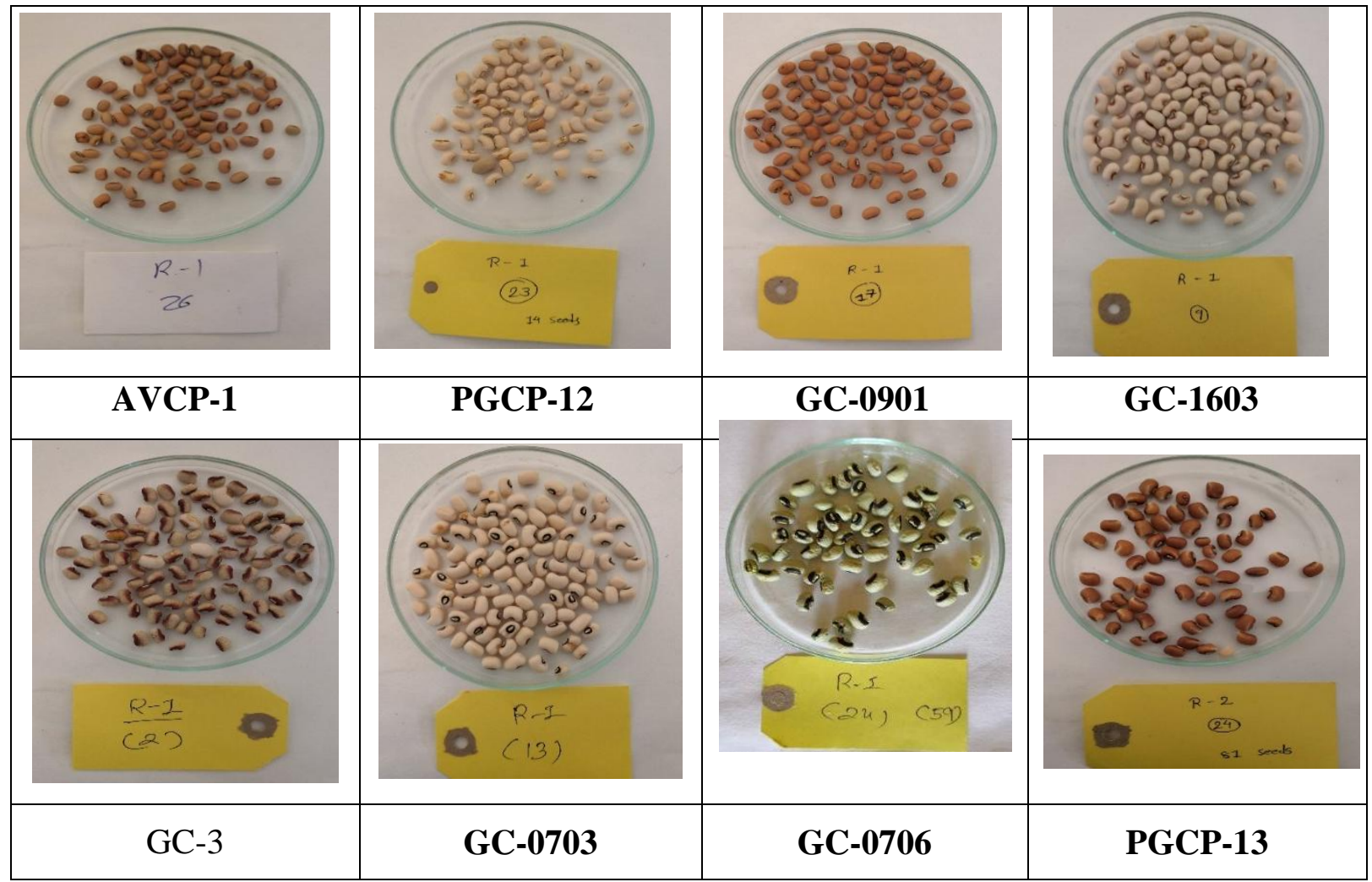

In conclusion, high estimates of GCV indicates more variability for the characters viz., number of seed per pod, number of pod per plant, seed yield per plant and leaf area per plant which indicate ample selection opportunity for these characters. The high heritability accompanied with high genetic advance as per cent of mean indicating predominance of additive gene action in the inheritance of number of pod per plant, number of seed per pod, pod length, test weight, seed yield per plant and leaf area per plant which can be improved by simple selection method. Correlation studies revealed the importance of characters viz. number of pod per plant, number of branch per plant, number of seed per pod and pod length for improving seed yield in cowpea. Most of the traits investigated here showed either positive or negative correlation with each other so it becomes difficult to combine all the desirable traits in one single genotype. Path coefficient analysis for seed yield per plant indicated that pod length, number of branch per plant, number of pod per plant and days to maturity had high positive direct effect on seed yield per plant and also showed highly significant and positive correlation with seed yield per plant except days to maturity which again fortifies the importance of above characters in crop improvement.

\section{Acknowledgements}

We are thankful to Pulse research station, Sardarkrushinagar for providing resources and Directorate of research, S.D.A.U., along with C. P. College of agriculture for providing research facility and funding to conduct the trial.

\section{Conflict of Interest}

Conflict of interest none declared. 


\section{References}

Aikins, S. H. M and Afuakwa, J. J. (2008). Growth and dry matter yield responses of cowpea to different sowing depth. Journal of Agricultural and Biological Science. 3(5): 50-54.

Anonymous, 2019. www.cowpea.com https://www.google.com/search?sxsrf=ACY B GNSnllMMHQdeMKqZGwlzFacfhjjvkQ\%3 A1574869530563\&ei=GpreXdeEIvfUz7sP0J aC-A0\&q=cow pea.com

Biradar, B. D., Goud, J. V. and Patil, S. S. (1993). Components of variance, heritability and genetic gain in cowpea. Annals of Agriculture Research, 14(4): 343-347.

Burton, G. W. (1952). Quantitative inheritance in grasses. Proceeding SixthInternational Grassland Congress.1: 277-283.

Cholin, S., Uma, M. S., Sangeeta, M., Suma, B. andSalimath, P. M.(2012). Legume Research. 35(1): 68-71.

Deepa, S. N. andBalan, A. (2006). Correlation studied in cowpea [Vigna unguiculata $(\mathrm{L}$. Walp.]. Madras Agricultural Journal. 93(712): 260-262.

Dewey, D. R. and Lu, K. H. (1959). A correlation and path analysis of components of crested wheat grass seed production. Agronomy Journal. 51:515-518.

Diouf, D. (2011) Recent advances in cowpea [Vigna unguiculata (L.) Walp.] "omics" research for genetic improvement. African Journal of Biotechnology 10(15): 2803-2810

Haile, J., Legesse, H. and Rao, C. P. (2015). Genetic Variability, Character Association and Genetic Divergence in Barley (Hordeum vulgare L.) Genotypes Grown at Horo District, Western Ethiopia. Science, Technology and Arts Research Journal. 4 (2): $1-9$.

ICAR-CCARI, 2019. ICAR-Central Coastal Agricultural Research Institute, Ela, Old Goa 403402, Retrieved from http://ccari.res.in/dss/cowpea.html

INSEE- The National Institute of Statistics and Economic Studies, France. 2019. Retrieved from https://www.insee.fr/en/metadonnees/definiti on/c1366
Jogdhande, S., Vijay, S. K. and Nagre, P. K. (2017). Correlation and path analysis study in cowpea [Vigna unguiculata (L.) Walp.] genotypes. International Journal of Current Microbiology and Applied Sciences. 6(6): 3305-3313.

Johnson, H. W., Robinson, H. E. and Comstock, R. E. (1955). Estimation of genetic and environmental variability in soyabean. Agronomy Journal. 47(7): 314-318.

Kamau, G. M. andWeru, S. M. (2001). Cowpea and maize rotation for soil fertility and soil management: State of the art document KARI. 29: 100-101.

Khan, H., Vishwanatha, K. P. andSowmya, H. C. (2013). Genetic variability and association studies in cowpea [Vigna unguiculata(L.) Walp.]. Journal of Food Legumes, 26(3-4): 42-45.

Khanpara, S. V., Jivani, L. L., Vachhani, J. H. andKachhadia, V. H. (2015). Genetic variability, heritability and genetic advance studies in vegetable cowpea [Vigna unguiculata(L.) Walp.]. Electronic Journal of Plant Breeding, 7(2): 408-413.

Kumar, R., Sangwan, R. S. and Singh, V. P. (2001). Correlation and path analysis in cowpea [Vigna unguiculata (L.) Walp.]. Forage Research, 27(1): 25-28.

Lal, H., Rani, M. and Karan, S. (2007). Multivariate hierarchical clustering ofcowpea germplasm [Vigna unguiculata (L.) Walp.]. Acta of Horticulture. 752(1): 113-117.

Narayankutty, C., Milli, R. andJaikumarm, U. (2003). Variability and genetic divergence in vegetable cowpea. Journal of Maharashtra Agricultural University, 28(1): 26-29.

Nigude, A. D., Dumbre, A. D., Lad, D. B. andBangar, N. D. (2004). Genetic variability and correlation studies in cowpea [Vigna unguiculata (L.) Walp.]. Journal of Maharashtra Agricultural University. 29(1):30-34.

Panse and Sukhatme (1978). Statistical method for Agricultural workers. Indian council of Agricultural Research, New Delhi. Pp.381.

Patel, U. V.,Parmar, V. K., Patel, P. B. and Malviya, A. V. (2016). Correlation and path analysis study in cowpea [Vigna unguiculata (L.) Walp.]. International Journal of Science, Environment and Technology, 6(5): 3897- 
3904.

Rangiah, S. and Mahadevu, P. (1999). Genetic variability, correlation and path analysis in cowpea. Madras Agriculture Journal, 86(79): 381-382.

Resmi, P. S., Celine, V. B. and Abdul V. M. (2004). Genetic variability in yard long bean [Vigna unguiculatasub sp. Sesquipedalis(L.) Vedcourt]. Legume Research, 27(4): 296298.

Sarath, P. S. andReshma, T. (2017). Genetic variability studies in cowpea [Vigna unguiculata $(\mathrm{L}$.$) \quad Walp.]. International$ Journal of Agriculture Science and Research (IJASR). 7(3):129-132.

Sarkar, S., Murmu, D., Chattopadhyay, A. and Hazra, P. (2009). Genetic variability, correlation and path analysis of some morphological characters in chilli. Journal of Crop and Weed. 5(1):157-161.

Sawant, D. S. (1994). Association and path analysis in cowpea. Annual of Agriculture Research, 15(2): 134-139.

Singh, B. B., Chambliss, O. L. and Sharma, B. (1997). Recent advances in cowpea. In: Singh, B.B., Mohan Raj, D.R., Dashiel, and Jackai, L.E.N. Advances in cowpea research. Co-publication of International Institute of Tropical Agriculture (IITA) and Japan International Research Center for Agricultural Sciences (JIRCAS), Ibadan, Nigeria. pp: 30-49.

Srinivas, J, Kale, V. S. andNagre, P. K. (2017). Study of genetic variability, heritability and genetic advance in cowpea [Vigna unguiculata (L.) Walp.]. International Journal of Current Microbiology and Applied Sciences. 6(6): 3314-3318.

Srinivas, J., Kale, V. S. andNagre, P. K. (2017). Correlation and path analysis in cowpea
[Vigna unguiculata (L.) Walp.] Genotypes. International journal of current microbiology and applied science. 6(6): 3305-3313.

Steel, W. M. (1976). Evolution of crop plant, ed. N. W. Simonds. Longman, London New York.

Thorat A. andGadewar R. D. (2013). Variability and correlation studies in cowpea [Vigna unguiculata(L.) Walp.]. International Journal for Environmental Rehabilitation and Conservation. 4(1): 44-49.

Udensi, O. and Ikpeme, E. V. (2012). Relationship studies in cowpea [Vigna unguiculata (L.) Walp.] landraces grown under humid low land condition. International Journal of Agriculture Research. 7(1): 3-45.

Vavilov, N. J. (1949). The origin, variation, immunity and breeding of cultivated plants. Chronica Botanica. 13: 364.

Vedcourt, B. (1970). Studies in leguminosepapillonoidae flora of tropicaleast Africa Kew Bulletin. 24: 556-569.

Venkatesan, A., Prakash, M. and Ganesan, J. (2003). Correlation and path analysis in cowpea [Vigna unguiculata (L.) Walp.]. Legume Research. 26(2):105-108.

Vir, O. and Singh, A. K. (2014). Genetic variability and inter-characters' associations studies in the germplasm of cowpea [Vigna unguiculata (L.) Walp.] in fragile climate of western Rajasthan. Indian Legume Research. 37(2): 126-132.

Vishwanath, H. L. and Rai, M. (2009). Hierarchical clustering and character association studies in cowpea. [Vigna unguiculata (L.) Walp.]. Indian Journal of Plant Genetic Resources. 22(1): 81-86.

\section{How to cite this article:}

Chaudhary, A. R., S. D. Solanki, P. M. Rahevar and Patel, D. A. 2020. Genetic Variability, Correlation and Path Coefficient Analysis for Yield and Its Attributing Traits in Cowpea [Vigna unguiculata (L.) Walp] Accessions. Int.J.Curr.Microbiol.App.Sci. 9(02): 1281-1293. doi: https://doi.org/10.20546/ijcmas.2020.902.151 